\title{
Sound Production by a Recoiling System in the Pempheridae and Terapontidae
}

\author{
Eric Parmentier, ${ }^{1 *}$ Michael L. Fine, ${ }^{2}$ and Hin-Kiu Mok ${ }^{3,4}$ \\ ${ }^{1}$ Laboratoire de Morphologie Fonctionnelle et Evolutive, AFFISH-RC, Institut de Chimie, Bât. B6c, Université de \\ Liège, Liège, B-4000, Belgium \\ ${ }^{2}$ Department of Biology, Virginia Commonwealth University, Richmond, Virginia 23284-2012 \\ ${ }^{3}$ Department of Oceanography and Asia-Pacific Ocean Research Center, National Sun Yat-sen University, Kaohsiung, \\ 80424, Taiwan \\ ${ }^{4}$ National Museum of Marine Biology and Aquarium, Checheng, Pingtung, 944, Taiwan
}

\begin{abstract}
Sound-producing mechanisms in fishes are extraordinarily diversified. We report here original mechanisms of three species from two families: the pempherid Pempheris oualensis, and the terapontids Terapon jarbua and Pelates quadrilineatus. All sonic mechanisms are built on the same structures. The rostral part of the swimbladder is connected to a pair of large sonic muscles from the head whereas the posterior part is fused with bony widenings of vertebral bodies. Two bladder regions are separated by a stretchable fenestra that allows forward extension of the anterior bladder during muscle contraction. A recoiling apparatus runs between the inner face of the anterior swimbladder and a vertebral body expansion. The elastic nature of the recoiling apparatus supports its role in helping the swimbladder to recover its initial position during sonic muscle relaxation. This system should aid fast contraction (between 100 and $250 \mathrm{~Hz}$ ) of sonic muscles. There are many differences between species in terms of the swimbladder and its attachments to the vertebral column, muscle origins, and morphology of the recoiling apparatus. The recoiling apparatus found in the phylogenetically-related families (Glaucosomatidae, Pempheridae, Terapontidae) could indicate a new character within the Percomorpharia. J. Morphol. 000:000-000, 2016. (C) 2016 Wiley Periodicals, Inc.
\end{abstract}

KEY WORDS: acoustic; swimbladder; communication; Percomorpha

\section{INTRODUCTION}

Fishes that produce sounds with the swimbladder utilize sonic muscles to vibrate the bladder wall. These muscles have various origins, insertions, ultrastructure, and contraction speeds (Fine and Parmentier, 2015; Parmentier and Fine, 2016). Intrinsic muscles attach completely to large areas of the swimbladder. Extrinsic sonic muscles insert on the swimbladder wall and have origins on various skull bones, the pectoral girdle, ribs or epineurals (Fine et al., 2001; Parmentier et al., 2014).

Generally, contractions of extrinsic and intrinsic sonic muscles produce short duration pulsed type sounds with fundamental frequencies less than several hundred $\mathrm{Hz}$ (Parmentier and Fine, 2016). Two main types of mechanism have been analyzed. (1) Sound can be produced as a forced response: the muscle contraction rate or time for a twitch determines sound fundamental frequency (Skoglund, 1961; Connaughton, 2004; Fine et al., 2001; Onuki and Somiya, 2004; Parmentier et al., 2011, 2014). In various catfish species (Boyle et al., 2014, 2015), the sonic muscles originate on the skull and insert on a bony modified rib (Müllerian ramus) that attaches to the swimbladder (Ladich and Bass, 1996). The muscle pulls the bladder forward through the spring mechanism. Sound production is due to the pull and rebound from the spring mechanism and stretched bladder. Again the fundamental frequency corresponds to the muscle contraction rate (Boyle et al., 2015). (2) The second main set of swimbladder mechanisms is less widespread among teleosts. The principle is to pull the rostral part of the swimbladder forward before releasing it. After relaxation, the rebound of the swimbladder sets surrounding hard tissues (ribs or bony plate) into resonance, which in turn causes multiple cycles of swimbladder vibration. In this case, the muscle contraction rate determines the pulse period but not the fundamental frequency (Parmentier et al., 2003; Kéver et al., 2012; Kéver et al., 2014a,b).

\footnotetext{
Contract grant sponsor: Ministry of Science and Technology, Taiwan, R.O.C.

*Correspondence to: Eric Parmentier, Laboratoire de Morphologie Fonctionnelle et Evolutive, AFFISH-RC, Institut de Chimie, Bât. B6c, Université de Liège, Liège, B-4000, Belgium. E-mail: E.Parmentier@ulg.ac.be
}

Received 11 November 2015; Revised 6 February 2016; Accepted 14 February 2016.

Published online 00 Month 2016 in Wiley Online Library (wileyonlinelibrary.com). DOI 10.1002/jmor.20529 
A similar but not identical recoiling apparatus was found in an unrelated perciform, the pearl perch Glaucosoma buergeri (Mok et al., 2011). It has an exceptional sonic mechanism consisting of a single-chambered swimbladder with two parts: the rostral part is free to move whereas the midline of the caudal part is firmly attached to the vertebral column. Relative movement between the two regions is aided by a stretchable swimbladder fenestra. Swimbladders consist of two main walls: the outer thick tunica externa and the thin tunica interna (Alexander, 1966; Alexander, 1981; Harden Jones, 1957). At the level of the swimbladder fenestra, the tunica externa is missing, so that the fenestra consists of thin pliable tunica interna. A pair of skeletal sonic muscles originates on the back of the skull and inserts on the outside of the rostral part of the bladder. A tendon from the ninth vertebra ends on a smooth muscle that attaches dorsally to the inner anterior part of the swim bladder. Contraction of the sonic muscle stretches the bladder, tendon and smooth muscle causing a weak sound putting the tendon and smooth muscle under strain. Rebound of the tendon and possibly the smooth muscle causes the bladder to snap back generating the intense part of the sound pulse (Mok et al., 2011).

Molecular systematics places Glaucosomatidae and Pempheridae are sister groups (Betancur-R et al., 2013), suggesting homologies in the anatomy of their sonic systems. Sounds and some elements of the sonic system have been described in the pempherids Pempheris adspersa in New Zealand (Radford et al., 2015), Pempheris schwenkii in Japan (Takayama et al., 2003) and Pempheris oualensis in Taiwan (Mok et al., 1997). Pempherids recorded in the wild make individual or series of harmonic pop sounds. The external morphology of the sound-producing system (i.e., the anterior sonic muscle) in silver sweeper Pempheris schwenkii resembles those of the glaucosomatid (Takayama et al., 2003). However, structures inside the swim bladder have not been described.

The Terapontidae is in a clade that is closely related but separate from the pempherids and glaucosomatids (Betancur-R et al., 2013). However, some members of both clades appear to share some anatomical similarities in their sonic systems. All terapontids (Vari, 1978) possess cylindrical sonic muscles between the skull and the anterior part of the swimbladder (Schneider, 1964). Again structures inside the swimbladder have not been described.

This study therefore examined the sounds and sonic anatomy of the pempherids Pempheris oualensis Cuvier, 1831 and two terapontids, the tigerfish Terapon jarbua (Forsskål, 1775) and the silver sweeper Pelates quadrilineatus (Bloch, 1790). These three species are united with Glaucosoma buergeri by the presence of a swimbladder fenestra and a snap back ligament connecting the vertebral column with the inside of the swimbladder.

\section{MATERIALS AND METHODS Acoustics}

Terapon jarbua and Pempheris oualensis were caught by hook-and-line at Kaohsiung City harbor, and Pelates quadrilineatus were caught at the estuary of Luermen River, Tainan County, Taiwan from May to September. Fish were brought back to the laboratory and placed individually in a (55.5 x 36.4 x $23.0 \mathrm{~cm}$ ) styrofoam box with fresh seawater (ca. 40 liters) for sound recording. Recordings were done under water at ca $25^{\circ} \mathrm{C}$. Fishes were gently held on its abdomen by hand, and the hydrophone was placed ca. $10 \mathrm{~cm}$ in front of their heads for recording. After recording fish were killed on ice and frozen for anatomical study.

Sounds were recorded with two separate systems. One included a hydrophone (Burns Electronics, Aquaear hydrophone MKII, frequency range: $10 \mathrm{~Hz}$ to $25 \mathrm{kHz}$, sensitivity: $-164 \mathrm{~dB}$ re $1 \mathrm{~V} / \mu \mathrm{Pa}$ ) connected to an amplifier (Burns Electronics, HPA1) and a digital recorder (KORG MR-1000, sampling rate: $44.1 \mathrm{kHz}, 16$ bits). In addition, an $\mathrm{H} 2 \mathrm{a}$ hydrophone (Aquarian audio products, frequency range: $1 \mathrm{~Hz}$ to $100 \mathrm{kHz}$, sensitivity: $-180 \mathrm{~dB}$ re $1 \mathrm{~V} / \mu \mathrm{Pa}$ ) connected to a digital recorder (SONY PCM-M10; sampling rate: $96 \mathrm{kHz}, 24$ bits) was also used. Terapon jarbua were recorded with the Korg MR-1 1000 system, and Pelates quadrilineatus and Pempheris oualensis were recorded with the Sony PCM M10 system. Sounds were recorded from three Terapon jarbua (Total length: $148 \mathrm{~mm}, 160$ $\mathrm{mm}, 170 \mathrm{~mm}$ ), six Pelates quadrilineatus (TL: $70 \mathrm{~mm}, 122 \mathrm{~mm}$, $126 \mathrm{~mm}, 130 \mathrm{~mm}, 140 \mathrm{~mm}, 144 \mathrm{~mm}$ ) and three Pempheris oualensis (TL: $120 \mathrm{~mm}$ and $131 \mathrm{~mm}$ ). Thirteen, 10 and 42 calls/ individual were recorded from Terapon jarbua, Pelates quadrilineatus and Pempheris oualensis respectively.

Acoustic data were analyzed using Avisoft-SASlab PRO software (Specht, 2002). We measured the number of pulses per call, call duration, pulse repetition rate, pulse duration, and pulse period (time between the beginning of two immediately adjacent pulses). Two different measures of frequency were recorded: the dominant frequency has the highest amplitude component (in either a broad-band or harmonic sound energy in the call) and the fundamental frequency that corresponds to the lowest frequency component in a harmonic sound. Since the fundamental frequency does not appear on all sonograms, we measured it using the power spectrum (logarithmic, bandwith $37 \mathrm{~Hz}$ ). Moreover, the sonic muscle contraction rate that drives the swimbladder one-for-one determines the fundamental frequency (Fine, 2012).

Protocols were approved by the Institutional Animal Care and Use Committee of National Sun Yat-sen University.

\section{Morphology}

Two each of Pelates quadrilineatus (Total Length, TL: 83 and $95 \mathrm{~mm}$ ), Pempheris oualensis (TL: 106 and $122 \mathrm{~mm}$ ) and Terapon jarbua (TL: 115 and $190 \mathrm{~mm}$ ) were dissected. Specimens of $T$. jarbua and $P$. quadrilineatus were purchased from the fish markets in Kaohsiung City. Specimens of Pempheris oualensis are from the group caught by hook-and-line at Kaohsiung City harbor. All these fish were fixed in $10 \%$ formalin.

Muscle insertions, skeletons, and swimbladder were examined with a Wild M10 binocular with a camera lucida. Small bands of tissue were observed on the inner dorsal side of the swimbladder. In order to compare the nature of this tissue with the smooth muscle in G. buergeri (Mok et al., 2011), samples were first fixed in glutaraldehyde $2.5 \%$ for histological study and then post-fixed in $1 \%$ osmium tetroxide, dehydrated through a graded ethanol-propylene oxide series and embedded in epoxy resin (SPI-PON 812, SPI-CHEM). Semithin (1 $\mu \mathrm{m})$ and ultrathin sections $(60-80 \mathrm{~nm})$ were cut using a diamond 

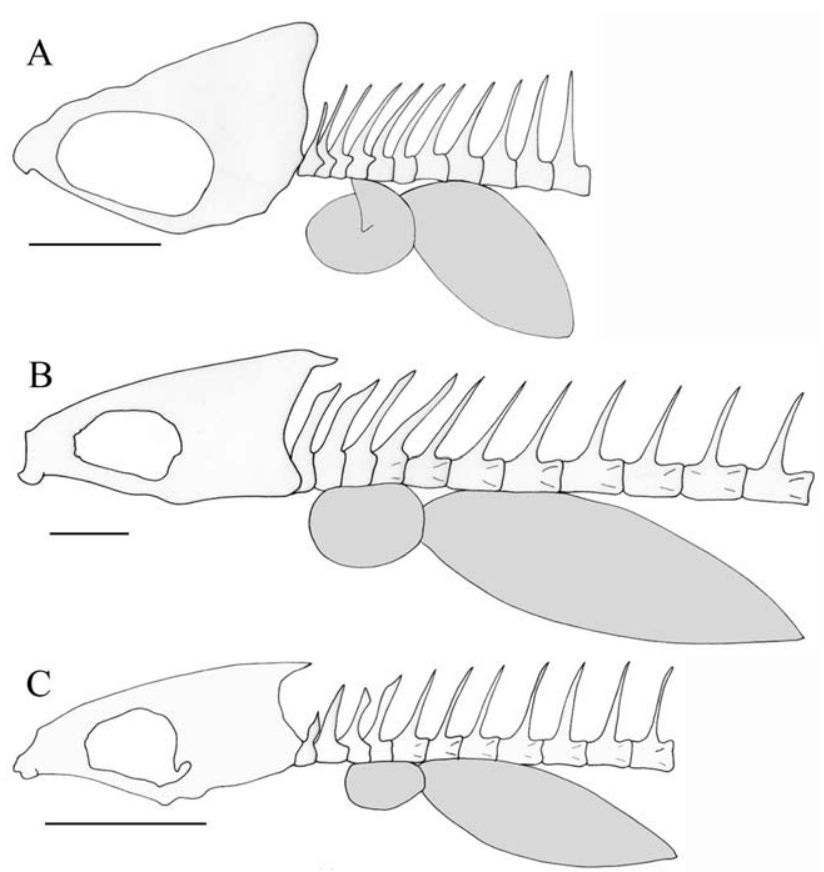

Fig. 1. Schematic left lateral views of skull, vertebral column and swimbladder in Pempheris oualensis (A), Terapon jarbua (B), and Pelates quadrilineatus (C). Skulls are shown at the same size. Scale bar: $10 \mathrm{~mm}$.

knife on a Reichert Ultracut E ultramicrotome (Leica). Toluidine blue-stained semithin sections were used for general histology and for orientation to target the area of further ultrathin sections. Ultrathin sections were classically stained with uranyl acetate and lead citrate and viewed in a JEOL JEM 100SX transmission electron microscope (JEOL Ltd., Tokyo, Japan) at $80 \mathrm{kV}$ accelerating voltage.

\section{RESULTS}

The three species have two-chambered bladders connected by a duct, and the anterior chamber is shorter than the posterior one (Fig. 1). The dorsal surface of the anterior chamber features a stretchable fenestra in the form of a narrow slit that runs perpendicularly to the longitudinal axis of the fish. This fenestra consists of a tunica interna that is not covered by an outer tunica externa. It allows displacement of only the anterior part of the anterior chamber when pulled by sonic muscles because the posterior part of the anterior chamber and the posterior chamber are attached to the vertebral column. A pair of cylindrical sonic muscles extends from the head or pectoral girdle (see below) and attaches to the dorsal part of the anterior chamber just forward of the fenestra (Fig. 2). Finally, a sheet of connective tissue in Pempheris oualensis and a pair of bulky connective tissue structures in Terapon jarbua and Pelates quadrilineatus, corresponding to a ligament, designated the recoiling system (Fig. 3), runs from its attachment on a ventral expansion of a vertebra to the inner side of the swimbladder. The recoiling system functions as an antagonist to the sonic muscles. These ligaments vary from being paired to partially and even totally fused. Histological studies (light microscopy and TEM) did not indicate smooth sonic muscles between the recoiling connective tissue and the swimbladder in any of the three species. The recoiling system appears mainly made of fibroblasts surrounded by an extracellular matrix having collagen fibers and ground substance (Fig. 4).

\section{Pempheris oualensis}

The anterior chamber of the swimbladder extends from the 3rd to the 6th vertebra, and the caudal chamber to the 9 th-11th vertebra (Fig. 1). Dorsally, folds of the tunica externa form a tube that attaches to parapohyses and lateral bony extensions from the ventral part of the vertebra 4 , 5, and 6 (Fig. 2). The tube forms a corridor for the two symmetric large sonic muscles. The muscles originate on the pterotics and insert dorsally on the swimbladder at the level of the 5th vertebra, just below its ventral bony expansion. The fenestra runs along the dorsal surface to the sides of the bladder. Inside the swimbladder, a small straight ligament, runs from the ventral bony expansion of the 6th vertebra to the inner side of the dorsal swimbladder, at the caudal end of the corridor (Figs. 2 and 3).

Harmonic calls of Pempheris oualensis consisted of trains of 2 to 9 pulses (Fig. 4A). Sound pulses were composed of three main cycles with the first one having the highest amplitude (Fig. 5). The first pulse had a greater amplitude than subsequent ones. Fundamental frequency varied from 107 to $121 \mathrm{~Hz}$, and the $3^{\text {rd }}$ harmonic had the most energy. Pulse duration was (mean $\pm \mathrm{SD}) 3.7 \pm 0.5 \mathrm{~ms}(\mathrm{n}=49)$. The mean value of the pulse period (the reciprocal of the muscle contraction rate) was $10 \pm 1 \mathrm{~ms}(\mathrm{n}=190)$ and appeared to drive the fundamental frequency. The mean sound duration $(49 \pm 23 \mathrm{~ms})$ was determined by the number of pulses.

\section{Terapon jarbua}

The anterior chamber extends from the 2nd to the 5 th vertebra, and the caudal from 5 th to the 11th vertebra (Figs. 1 and 2). The caudal part of the anterior chamber is tightly connected dorsally to a lateral bony expansion of the fourth vertebra The sonic muscles originate on the medial side of the pectoral girdle, on both the distal part of the posttemporal and the proximal part of the supracleithrum and insert dorsally on the anterior chamber, forward of the bony expansion of the fourth vertebra. Two previously undescribed ligaments connect the ventral side of the bony expansion of the 4 th vertebra to the inner rostral part of the swimbladder (Fig. 3).

Calls of Terapon jarbua consisted of trains of 12 to 24 pulses with an average duration of $81 \pm 15$ 


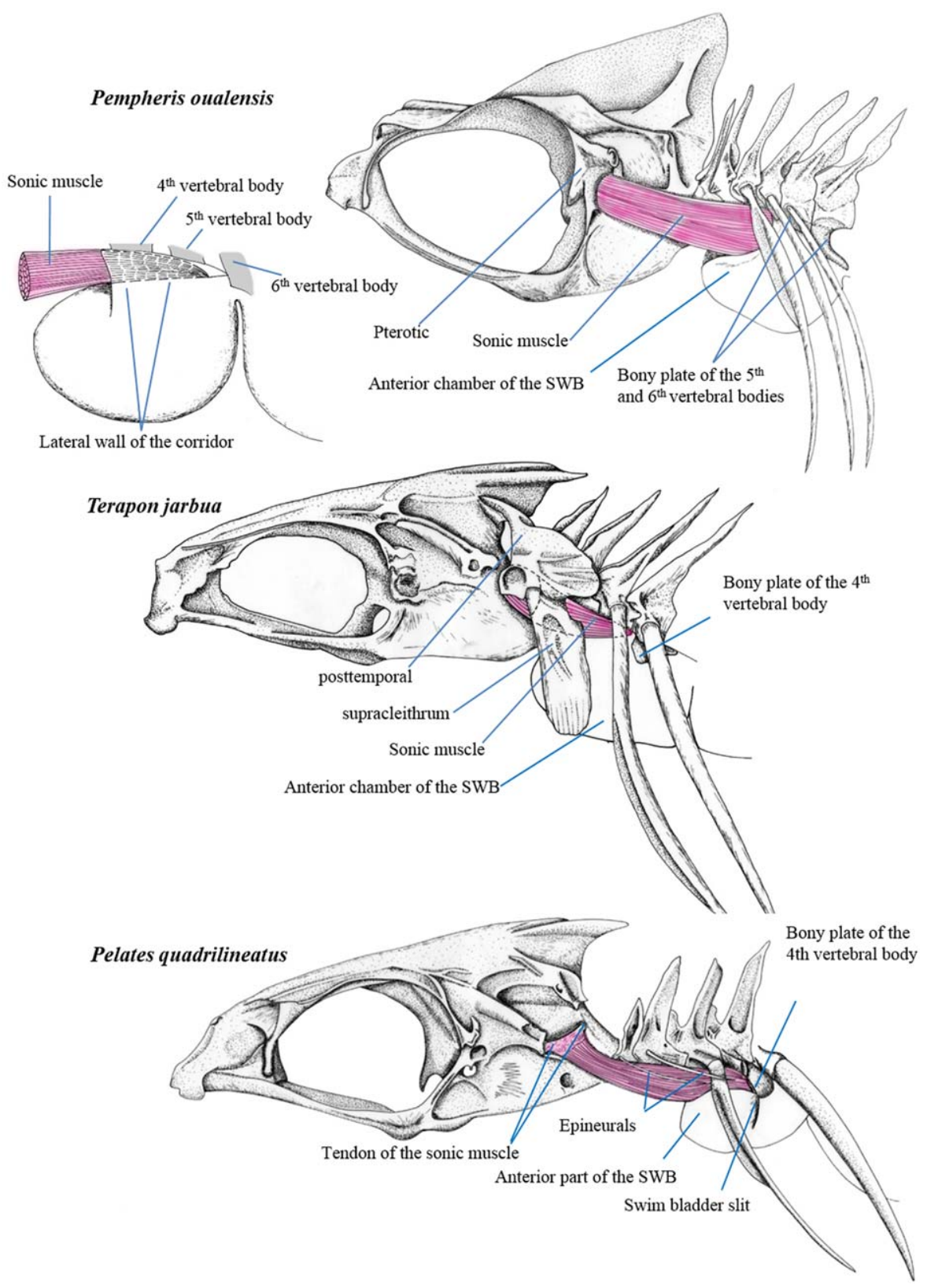

Fig. 2. Left lateral views of the sound-producing apparatus in Pempheris oualensis, Terapon jarbua and Pelates quadrilineatus. The rib of the 6th vertebra and of the 4th vertebra are removed to see the bony widenings of the vertebrae in $P$. oualensis and $P$. quadrilineatus respectively. The sonic muscle origin is on the medial side of the pectoral girdle (only the dorsal part is shown) in $T$. jarbua. In P. oualensis, the figure on the left shows in left lateral view the anterior chamber of the swimbladder. Left and right lateral walls attach to the vertebral bodies and form a corridor for the sonic muscles that insert on the outer wall of the swimbladder, in the caudal part of the corridor.

ms $(n=15)$ (Fig. 5B). Sound pulses were composed of three main cycles with the second one having the highest amplitude. Pulses were relatively similar in amplitude. The sound had up to 13 harmonics and fundamental frequency varied from 170 to $260 \mathrm{~Hz}$; most of the energy occurred in the 2nd to 5 th harmonic. The mean value of the pulse period was $5 \pm 0.6 \mathrm{~ms}(n=54)$, meaning it can correspond to the muscle contraction rate that drives the fundamental frequency.
Each pulse consisted of two main cycles although the amplitude of the first cycle was half that of the second cycle (Fig. 6). The amplitude attenuated rapidly after the second cycle.

\section{Pelates quadrilineatus}

The anterior chamber extends from the 3rd to the 6th vertebra, and the posterior chamber extends to the 11th vertebra (Fig. 1). The dorsal 


\section{Pempheris oualensis}

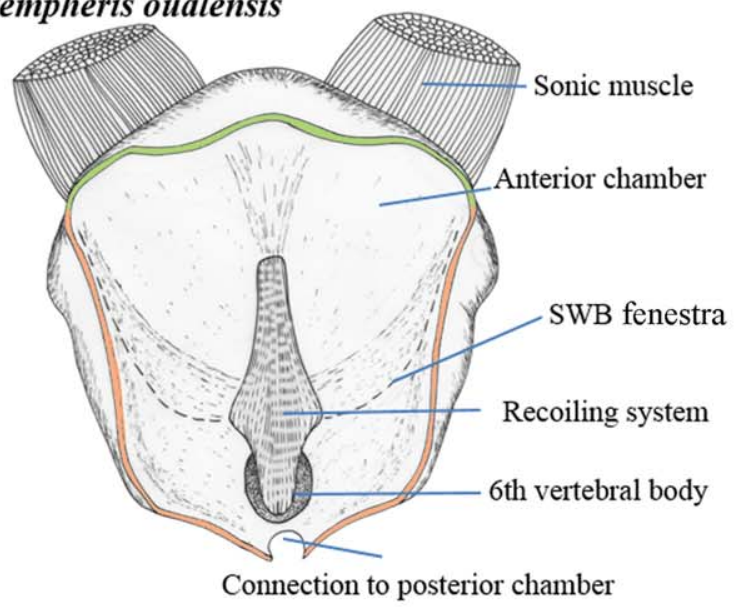

\section{Terapon jarbua}
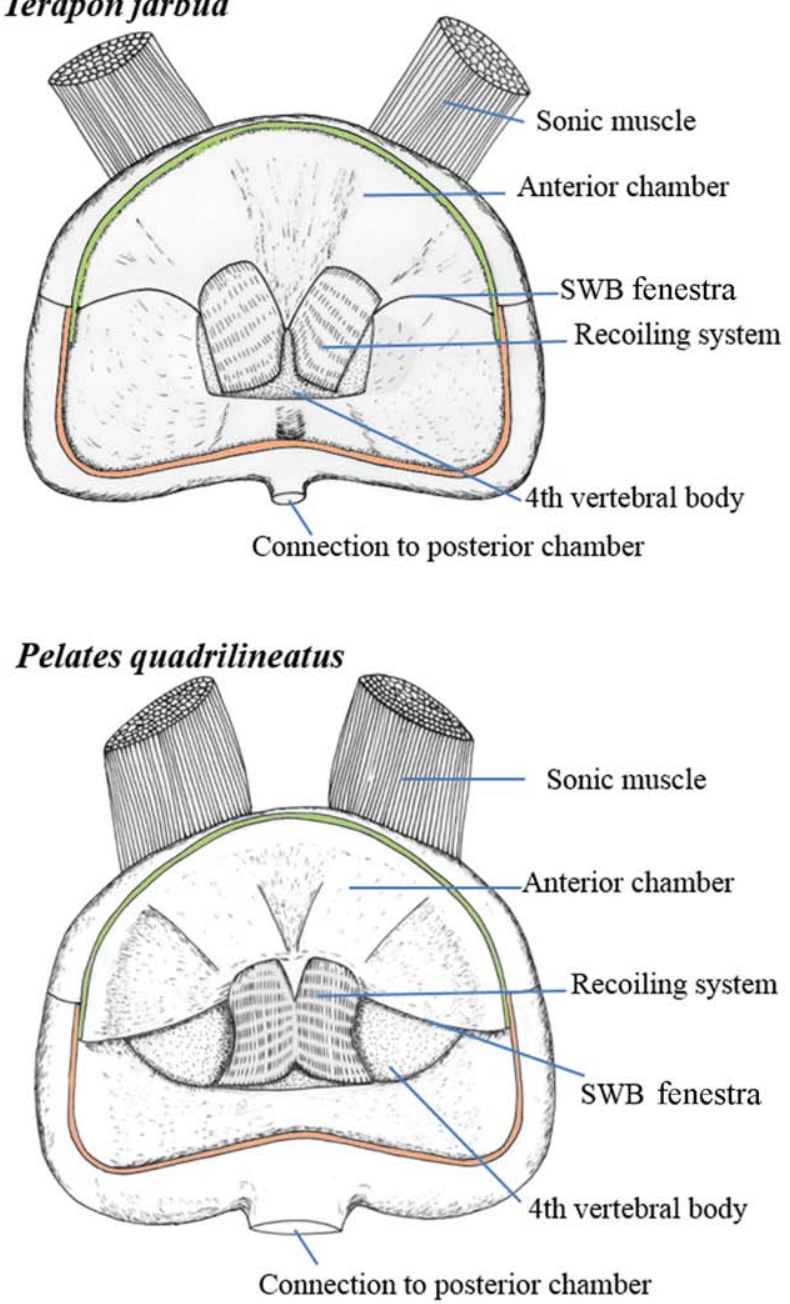

Fig. 3. Ventral view of the dorsal wall of the swimbladder (base of the swimbladder removed) illustrating the attachment of recoiling system.

part of the anterior chamber attaches to the bony expansion of the 4 th vertebra. The caudal edge of the swimbladder fenestra also attaches to the 4th vertebra. The origins of the sonic muscles form two points of tendinous attachments to the epioccipital (=epiotic). The muscles insert dorsally on the swimbladder at the level of the 4 th vertebra. The anterior part of the swimbladder possesses two ligaments that are largely fused and attach caudally to the 4 th vertebra and rostrally to the inner side of the swimbladder (Fig. 3).

Calls of Pelates quadrilineatus are short and long sounds reminiscent of Morse code although it is unclear if the unusual patterning conveys specific messages. Sounds lasted from 30 to $470 \mathrm{~ms}$ $(84 \pm 15 \mathrm{~ms}, n=15)$ and consisted of trains of 8 to 73 pulses (Fig. 5C). Sound had up to 14 harmonics, and fundamental frequency varied from 235 to $280 \mathrm{~Hz}$ with most energy in the 2nd and the 3rd
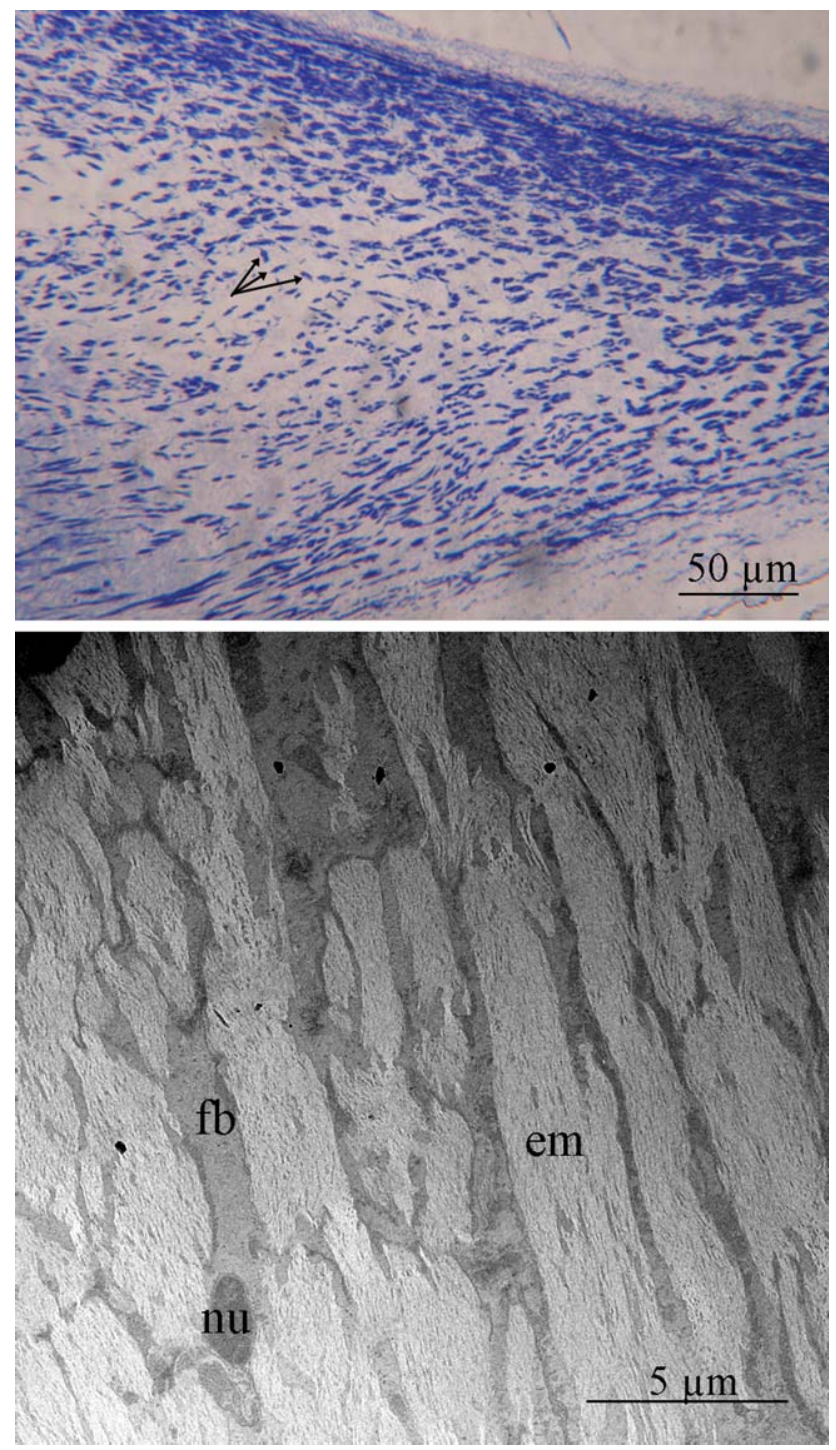

Fig. 4. Frontal histological section (A) and SEM picture (B) at the level of the recoiling system in Pempheris oualensis. em: extracellular matrix; fb: fibroblast; nu: nucleus of the fibroblast; black arrows: fibroblasts. 

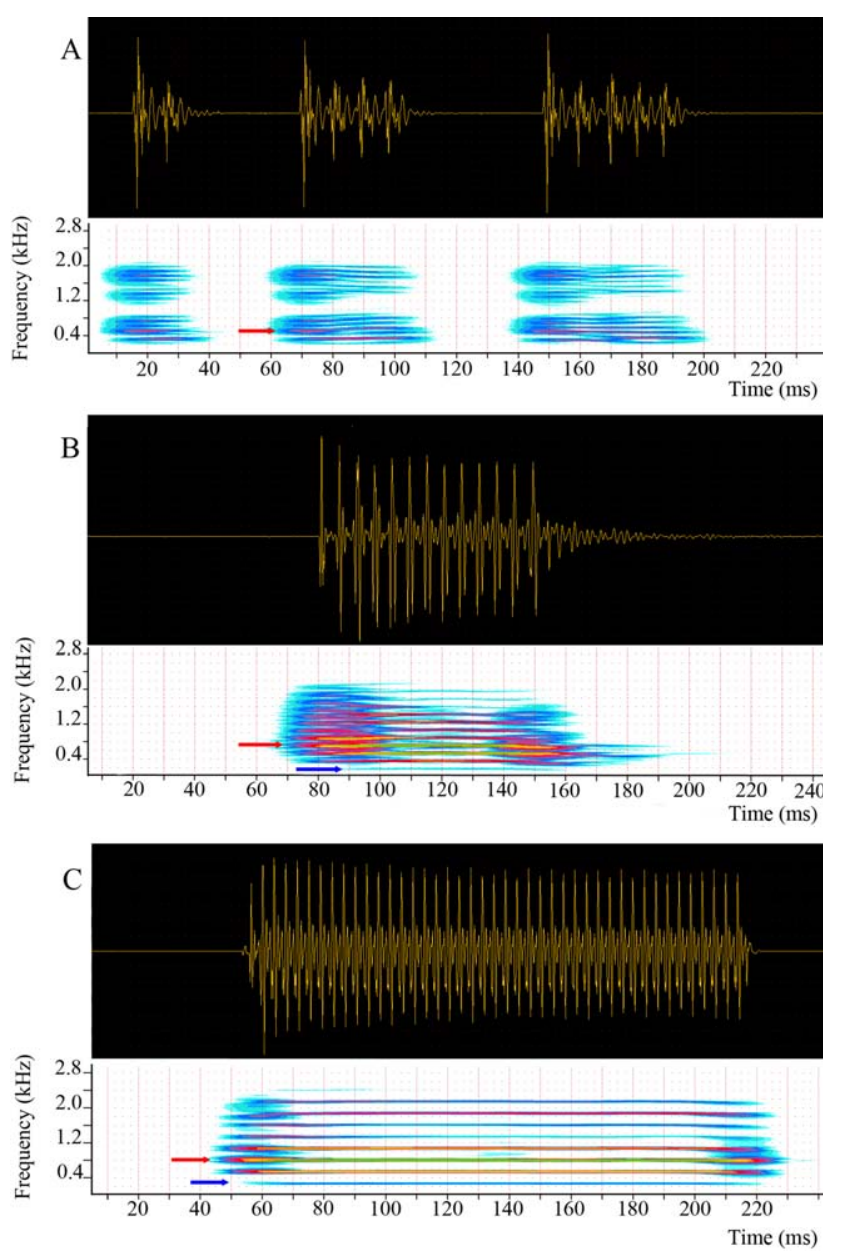

Fig. 5. Oscillograms and sonagrams of the pulse trains in Pempheris oualensis (A), Terapon jarbua (B), and Pelates quadrilineatus (C). Blue arrows: fundamental frequency, red arrows: dominant frequency. FFT size: 1024.

harmonics. Pulse duration was $5 \pm 0.8 \mathrm{~ms}(n=49)$. The mean value of the period being $3.9 \pm 0.3 \mathrm{~ms}$ $(n=92)$, and the muscle contraction rate likely generates the fundamental frequency. Sound pulses were composed of three cycles, the second one having the highest amplitude (Fig. 6).

\section{Glaucosoma buergeri}

\section{DISCUSSION}

Sounds of Glaucosoma buergeri were issued as a series of pulses (Mok et al., 2011) separated by greater interpulse intervals than in the continuous tonal sounds of the other three species. In comparison to P. oualensis, T. jarbua, and P. quadrilineatus, pulses in $G$. buergeri started with a low amplitude negative half cycle, and continued for at least two cycles (Fig. 5). Each cycle was lower in amplitude and longer than the preceding one. After a pause of several milliseconds there were two high-amplitude cycles starting with a loweramplitude positive half cycle.

The sonic mechanism in the glaucosomatids, pempherids, and terapontids is united at least by (1) anterior insertions of sonic muscles from the head/pectoral girdle to the dorsorostral swimbladder, (2) a swimbladder fenestra, (3) attachments to bony enlargements of the vertebral bodies of posterior regions of the bladder which restrict movement, and (4) a snap-back system that facilitates recoil of the anterior bladder. Unlike the other three species, Glaucosoma buergeri has a singlechambered bladder, and the recoiling system is made of a tendon that connects to the swimbladder
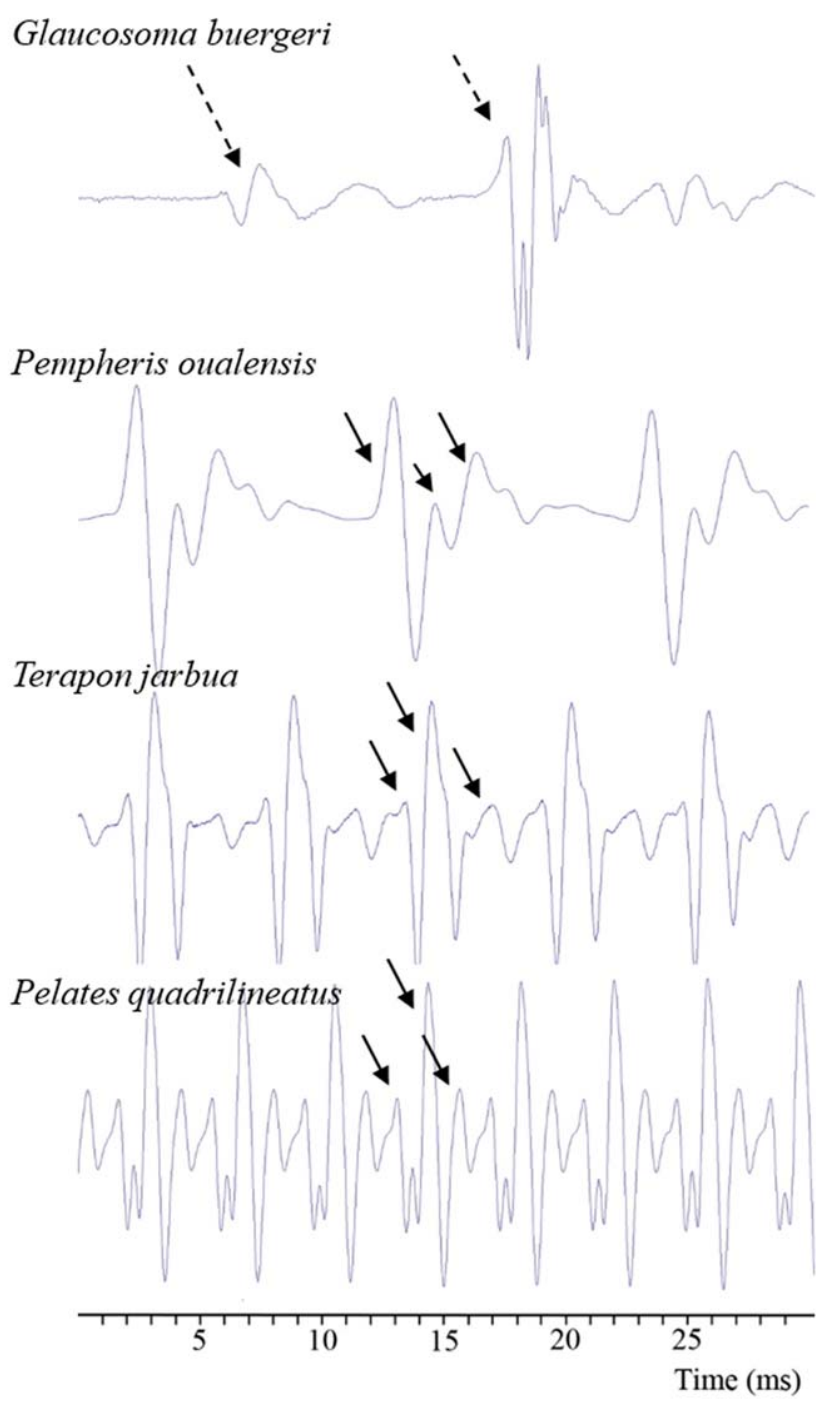

Fig. 6. Expanded oscillograms of a pulse from a train in Glaucosoma buergeri and several pulses from Pempheris oualensis, Terapon jarbua, and Pelates quadrilineatus. We suggest each major peak corresponds to a snap-back movement. Dotted arrows show the two main part of the pulse in Glaucosoma buergeri. Single arrows show the three peaks of each pulse in the other species. Graph concerning $G$. buergeri was obtained from the data found in Mok et al. (2011). 
via a smooth muscle (Mok et al, 2011). The other three species have added an additional chamber with the posterior part of the anterior chamber behind the fenestra as well as the posterior chamber fused to vertebral-body expansions. In all four species the anterior part of the swimbladder is free to move, and movement of the swimbladder behind the fenestra is restricted by the vertebral attachments. The elastic nature of the recoiling apparatus supports its role in helping the swimbladder to recover its initial position during relaxation of the sonic muscles. The recoiling apparatus should expedite the muscle return to its resting position and therefore ready it for the next contraction. There are however, morphological differences in the three species: the sonic muscles have different origins including the skull, the pectoral girdle or both, and the recoiling system attaches to different vertebrae and varies in its degree of fusion and points of attachment to different vertebrae.

This snap-back mechanism highlights the great diversity of mechanisms in fishes and raises interesting evolutionary questions since such a structure is currently unknown in other sonic fishes. Because the glaucosomatids and pempherids are sister taxa, it is likely that the recoiling apparatus is homologous in these two families that were recently grouped in the Pempheriformes (Betancur-R et al., 2013). The Terapontidae are in a separate but neighboring clade from the other two families. Vari (1978) noted an extrinsic sonic muscle and transversely divided swimbladder were synapomorphies of the Terapontidae, suggesting all the species of the family should be able to make sounds. According the recent paper by Sanciangco et al. (2016), the new suborder Terapontoidei includes (Girella, (Dichisticus ((Kuhlidae, Oplegnathidae) (Terapontidae, Kyphosidae)))); Terapontidae is the sister-group for Kyphosidae. The vocal families Kyphosidae and Oplegnathidae are nested within the terapontid clade. In Oplegnathus fasciatus, a pair of extrinsic muscle originates on the exoccipital and inserts on the anterior end of the swimbladder (Nakazato and Takemura, 1987). Sounds have been recorded in Kyphosus sectatrix, but the authors simply noted the sounds were made by the swimbladder (Fish and Mowbray, 1970). Both the Kyphosidae and Oplegnathidae require further examination to determine if a snap-back structure is present, which would then be a synapomorphy uniting the two clades.

There are major differences in the sounds of the four species because the pearl perch Glaucosoma buergeri produces sound pulses (Mok et al., 2011), and the other three species can produce longduration tonal sounds. Ultrastructure of the sonic muscles and short cycle time in the pre-pulse supports superfast contractions in the pearl perch. Each pulse was made of two parts, and the amplitude of the second part was considerably greater than that of the first one (Fig. 5). Therefore the second set of cycles is likely the more effective part of the call. This system is analogous to a mechanical system with a spring and dashpot, the tendon and smooth muscle respectively. The dash pot would function to damp swimbladder vibrations although it might contribute to rebound since smooth muscles can contract when stretched (Webb, 2003). The present finding that the other three species with no smooth muscles produce continuous tonal sounds is consistent with the damping hypothesis for the smooth muscle.

In species like the oyster toadfish (Fine, 2012; Fine et al., 2001) and red piranha (Millot et al., 2011) in which the swimbladder is driven directly by superfast sonic muscles, sound is produced as a forced response determined by muscle contraction rate. Such sounds damp quickly, have a relatively low frequency spectrum (most energy will be below $1 \mathrm{kHz}$ ) and each half cycle of waveform increases in duration following the final muscle contraction. Pulse frequencies between 100 and $250 \mathrm{~Hz}$ indicate that sounds in the three species are stimulated by superfast muscles as supported morphologically in Terapon jarbua (Chen et al., 1998; Eichelberg, 1976). This system provides calls with multiple harmonics. We note however that the timing of the various cycles was inconsistent suggesting complex modes of sound generation. The periods of various cycles in a pulse change in a variable manner likely caused by driving forces of muscle and ligament interacting with natural oscillation of the swimbladder. Such variability is atypical of fish sounds. Despite speciesspecific variations in waveform, similarities support a common sonic mechanism in these species. For this reason, we suppose also the high dominant frequency recorded in Pempheris adspersa (Radford et al., 2015) corresponds in fact to a higher harmonic rather than the fundamental frequency. In Pempheris adspersa trains, the pulse period (i.e. the duration between the onset of two consecutive pulses) in fused pops varies from 5 to $8 \mathrm{~ms}$ (equivalent to 200 and $125 \mathrm{~Hz}$ respectively) whereas the dominant frequency is between 304 and $405 \mathrm{~Hz}$.

The recording of hand-held disturbance calls does not allow interpretation of their function in acoustic behavior. Such sounds show at least that stress can motivate sound production, and calls may also serve as a warning signal to conspecifics or predators (Kaatz, 2002; Bosher et al., 2006). In Pempheris adspersa, vocalizations may function as contact calls for maintaining school cohesion (Radford et al., 2015). Sounds were also observed during approach of a school of Pempheris schwenkii suggesting they possibly function as a threat to heterospecific intruders (Takayama et al., 2003). Members of the Terapontidae family make sounds when caught by fishers or prior to a predatory attack (Bessey and Heithaus, 2013). Therefore, the recoiling mechanism appears related to the production of alarm or grouping calls. 
Fast sonic muscle would provide calls whose frequencies provide little information on the emitter's size (Parmentier and Fine, 2016) although other cues such as amplitude or calling effort could provide important information (Vasconcelos 2012).

\section{ACKNOWLEDGMENTS}

None of the authors have a conflict of interest issue with this submission. Authors are grateful to the constructive remarks of anonymous referees.

\section{LITERATURE CITED}

Alexander RM. 1966. Physical aspects of swimbladder function. Biol Rev 41:141-176.

Alexander RM. 1981. The Chordates. Cambridge: Cambridge University Press.

Bessey C, Heithaus MR. 2013. Alarm call production and temporal variation in predator encounter rates for a facultative teleost grazer in a relatively pristine seagrass ecosystem. J Exp Mar Biol Ecol 449:135-141.

Betancur-R R, Broughton RE, Wiley EO, Carpenter K, López JA, Li C, Holcroft NI, Arcila D, Sanciangco M, Cureton II JC, Zhang F, Buser T, Campbell MA, Ballesteros JA, Roa-Varon A, Willis S, Borden WC, Rowley T, Reneau PC, Hough DJ, Lu G, Grande T, Arratia G, Ortí GP. 2013. The Tree of Life and a New Classification of Bony Fishes. Edition 1. Plos Currents Tree of Life 5:18.

Bosher B, Newton S, Fine M. 2006. The spine of the channel catfish, Ictalurus punctatus, as an anti-predator adaptation: An experimental study. Ethology 112:188-195.

Boyle KS, Colleye O, Parmentier E. 2014. Sound production to electric discharge: Sonic muscle evolution in progress in Synodontis spp. catfishes (Mochokidae). Proc R Soc B 281.

Boyle KS, Riepe S, Bolen G, Parmentier E. 2015. Variation in swim bladder drumming sounds from three doradid catfish species with similar sonic morphologies. J Exp Biol 218: 2881-2891.

Chen SF, Huang BQ, Chien YY. 1998. Histochemical characteristics of sonic muscle fibers in tigerperch, Terapon jarbua. Zool Stud 37:56-62.

Connaughton MA. 2004. Sound generation in the searobin (Prionotus carolinus), a fish with alternate sonic muscle contraction. J Exp Biol 207:1643-1654.

Eichelberg H. 1976. The fine structure of the drum muscles of the tigerfish Therapon jarbua, as compared with the trunk musculature. Cell Tissue Res 174:453-463.

Fine ML. 2012. Swimbladder sound production: the forced response versus the resonant bubble. Bioacoustics 21:5-7.

Fine ML, Parmentier E. 2015. Mechanisms of sound production. In: Ladich F, editor. Sound Communication in Fishes. Wien: Springer. pp 77-126.

Fine ML, Malloy KL, King CB, Mitchell SL, Cameron TM. 2001. Movement and soung generation by toadfish swimbladder. J Comp Physiol a 187:371-379.

Fish MP, Mowbray HM. 1970. Sounds of Western North Atlantic Fishes. Baltimore: The Johns Hopkins Press. 207 p.

Harden Jones FR. 1957. The swimbladder. In: Brown HE, editor. The Physiology of Fishes Vol II Behaviour. New York: Academic Press. pp 305-322.

Kaatz IM. 2002. Multiple sound-producing mechanisms in teleost fishes and hypotheses regarding their behavioral significance. Bioacoustics 12:230-233.

Kéver L, Boyle K, Dragicevic B, Dulcic J, Casadevall M, Parmentier E. 2012. Sexual dimorphism of sonic apparatus and extreme intersexual variation of sounds in Ophidion rochei (Ophidiidae): First evidence of a tight relationship between morphology and sound characteristics in Ophidiidae. Front Zool 9:34.

Kéver L, Boyle KS, Bolen G, Dragicevic B, Dulcic J, Parmentier E. 2014a. Modifications in call characteristics and sonic apparatus morphology during puberty in Ophidion rochei (Actinopterygii: Ophidiidae). J Morphol 275:650-660.

Kéver L, Colleye O, Lugli M, Lecchini D, Lerouvreur F, Herrel A, Parmentier E. 2014b. Sound production in Onuxodon fowleri (Carapidae) and its amplification by the host shell. J Exp Biol 217:4283-4294.

Ladich F, Bass AH. 1996. Sonic/vocal-acousticolateralis pathways in teleost fishes: A transneuronal biocytin study in mochokid catfish. J Comp Neurol 374:493-505.

Millot S, Vandewalle P, Parmentier E. 2011. Sound production in red-bellied piranhas (Pygocentrus nattereri, Kner): An acoustical, behavioural and morphofunctional study. J Exp Biol 214:3613-3618.:

Mok HK, Yeh MW, Kuo SC. 1997. Sound characteristics and diurnal vocal activity of sweepers, Pempheris oualensis (Pempheridae, Perciformes). Proc Natl Sci Coun Repub China B 21:175-179.

Mok H-K, Parmentier E, Chiu K-H, Tsai K-E, Chiu P-H, Fine M. 2011. An Intermediate in the evolution of superfast sonic muscles. Front Zool 8:31-

Nakazato M, Takemura A. 1987. Acoustical behavior of Japanese parrot fish Oplenathus fasciatus. Nippon Suisan Gakk 53:967-973.

Onuki A, Somiya H. 2004. Two types of sounds and additional spinal nerve innervation to the sonic muscle in John Dory, Zeus faber (Zeiformes: Teleostei). J Mar Biol Assoc U K 84: 843-850.

Parmentier E, Fine ML. 2016. Fish sound production: An exaptation? In: Suthers R, Tecumseh F, Popper AN, Fay RR, editors. Vertebrate Sound Production and Acoustic Communication. New York: Springer.

Parmentier E, Vandewalle P, Lagardère JP. 2003. Sound-producing mechanisms and recordings in Carapini species (Teleostei, Pisces). J Comp Physiol a 189:283-292.

Parmentier E, Vandewalle P, Brie C, Dinraths L, Lecchini D. 2011. Comparative study on sound production in different Holocentridae species. Front Zool 8:12-

Parmentier E, Tock J, Falguière J-C, Beauchaud M. 2014. Sound production in Sciaenops ocellatus: Preliminary study for the development of acoustic cues in aquaculture. Aquaculture 432:204-211.

Radford CA, Ghazali S, Jeffs AG, Montgomery JC. 2015. Vocalisations of the bigeye, Pempheris adspersa: Characteristics, source level, and active space. J Exp Biol 218:940-948.

Sanciangco MD, Carpenter K, Betancur-R R. 2016. Phylogenetic placement of enigmatic percomorph families (Teleostei: Percomorphaceae). Mol Phyl E 94:505-576.

Schneider H. 1964. Physiologische und morphologische Untersuchungen zur Bioakustik der Tigerfische (Pisces, Theraponidae). Z Vgl Physiol 47:493-558.

Skoglund C. 1961. Functional analysis of swimbladder muscles engaged in sound production of the toadfish. J Biophys Biochem Cytol 10:187-200.

Takayama M, Onuki A, Yosino T, Yoshimoto M, Ito H, Kohbara J, Somiya H. 2003. Sound characteristics and the sound producing system in silver sweeper, Pempheris schwenkii (Perciformes: Pempheridae). J Mar Biol Assoc U K 83:1317-1320.

Vari RP. 1978. The Terapon perches (Percoidei, Teraponidae). A cladistic analysis and taxonomic revision. Bull Am Mus Natl Hist 159:175-340.

Webb RC. 2003. Smooth muscle contraction and relaxation. Adv Physiol Educ 27:201-206. 